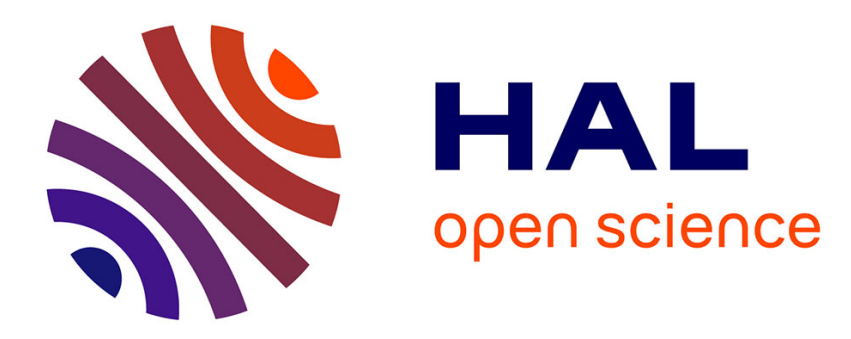

\title{
The second generation of ecological economics: How far has the apple fallen from the tree?
}

\author{
Gaël Plumecocq
}

\section{To cite this version:}

Gaël Plumecocq. The second generation of ecological economics: How far has the apple fallen from the tree?. Ecological Economics, 2014, 107, pp.457 - 468. 10.1016/j.ecolecon.2014.09.020 . hal-01089457

\section{HAL Id: hal-01089457 \\ https://hal.science/hal-01089457}

Submitted on 1 Dec 2014

HAL is a multi-disciplinary open access archive for the deposit and dissemination of scientific research documents, whether they are published or not. The documents may come from teaching and research institutions in France or abroad, or from public or private research centers.
L'archive ouverte pluridisciplinaire HAL, est destinée au dépôt et à la diffusion de documents scientifiques de niveau recherche, publiés ou non, émanant des établissements d'enseignement et de recherche français ou étrangers, des laboratoires publics ou privés. 


\title{
The second generation of ecological economics: How far has the apple fallen from the tree?
}

\author{
Gaël Plumecocq \\ French National Institute for Agricultural Research, INRA - UMR AGIR \\ Chemin de Borde-Rouge - Auzeville \\ CS 52627, 31326 Castanet-Tolosan, France \\ Email: gael.plumecocq@toulouse.inra.fr
}

Keywords: Discourse analysis; Ecological economics; Environmental economics; Editorial choices; Textual data processing.

\section{Highlights}

- The paper analyzes 6,237 abstracts of articles published in four journals since 1989.

- I have examined how scientific discourse produced in Ecological Economics has evolved.

- Ecological economics discourse is converging toward environmental economics.

- The valuation of ecosystem services discourse has become central in ecological economics.

- The prevalence of pragmatism in the field and in the editorial boards explains this trend.

\begin{abstract}
:
This paper examines the discourse produced in the academic journal Ecological Economics from its inception in 1989, and compares this discourse with that of the field of environmental economics. I used methods for discourse analysis (Alceste and Iramuteq) on 6,308 abstracts of papers published in four journals - namely Ecological Economics, the Journal of Environmental Economics and Management, Environmental Values, and Environmental and Resource Economics, published between 1989 and 2013. The results suggest that the discourse of ecological economics and environmental economics have grown closer over time. The semantic classification of co-occurrent terms used in Ecological Economics indicates increasing significance of the notions of ecosystem services and of monetary valuation. I argue that this trend is parallel to Costanza's career-path, which suggests the rise of a tacit recognition of the New Environmental Pragmatic scientific approach. I conclude with some of the implications for EE of promoting this kind of discourse to such an extent.
\end{abstract}




\section{Introduction}

In recent years, articles have been published envisaging the future of ecological economics (Spash, 2011; Anderson and M'Gonigle, 2012; Spash, 2012). These articles have echoed and increased the large number of publications analyzing ecological economics. In this line of research, we can distinguish historical analysis and reports from personal experience (Spash, 1999; Pearce, 2002; Costanza, 2003; Røpke, 2004, 2005; Spash, 2006) and from more normative works defining the goal of ecological economics (Costanza, 1989; Norgaard, 1989; Van den Bergh, 2001; Özkaynak et al., 2002; Gowdy and Erickson, 2005a; Spash, 2012; Martinez-Alier, (forthcoming)). Although both kinds of research aim at finding common ground for the community of researchers, they also employ discourse on the reasons why we should adopt an ecological economics approach towards environmental problems (Luks, 1998). As a result, from individual researchers' perspectives, they define what 'good' ecological economists should be.

The purpose of this paper is to analyze this discourse produced by ecological economics since the emergence of the field in 1989, and examine the relationship between the second generation of ecological economics and the origins of the movement. Evidence of these discourses can be found in academic journals of the ecological economics community, and in particular, Ecological Economics (EE hereafter). Of course, the discourse of ecological economics is not exhaustively summarized in the articles published in EE, and the authors published in the journal are often distantly related to the community if at all. Yet, EE articles can be used as representative of the discourse prevailing in the field because EE has institutional rules and organizational structures ensuring that the articles published, in addition to meeting academic standards, are also consistent with the paradigms prevailing in the field. To a certain extent, the principles and procedures of decision-making for publication in $\mathrm{EE}$ complies with the normative requisites prevailing in the field. For instance, when selecting new members for the editorial board in 2009, the Editor-in-Chief wrote, "These individuals were selected to provide service opportunities to new members of the ecological economics community, taking into account the journal's evolving intellectual focus and the increasingly international scope of our field. Selections were made by the Editor-in-Chief in close consultation with the publisher and the leaders of the International Society for Ecological Economics" (Howarth, 2009, p. 593).

Analyzing scientific discourse requires considering that the production of knowledge is about defining narratives. The second section of this paper investigates the ways in which articles published in academic journals can be considered as discourses and analyzed as such. The third section then questions the discourses produced in ecological economics through textual analysis of abstracts by (i) comparing the evolution of environmental and ecological economics discourses and (ii) studying the evolution of the semantic content of the EE publications. Abstracts of articles published in EE, in the Journal of Environmental Economics and Management (JEEM), in Environmental Values (EV), and in Environmental and Resource Economics (ERE) between 1989 and 2013 have been processed with innovative methods of textual data analysis, namely Alceste (Reinert, 1983, 1990) and Iramuteq (Ratinaud and Dejean, 2009) software. Results presented in the fourth section suggest that ecological economics discourse is evolving towards convergence with environmental economics discourse. Following Illge and Schwarze (2009), there are some common points between ecological and environmental economics (Gowdy and Erickson, 2005b; Spash and Ryan, 2012). Results in this study particularly point to the increasing importance of the evaluation of ecosystem services in ecological economics discourse. Finally, I discuss this trend and interpret it as the prevalence of an academic convention supported by (i) the ambition to improve EE's success and (ii) the justification of a pragmatist paradigm (Section 6). I conclude by questioning the kind of transdisciplinarity promoted by ecological economics.

\section{Talking about Discourse in Ecological Economics}

Post-modern science not only follows from the need to address complex issues in a fast-changing world, it also acknowledges the fact that research must address urgent societal issues (Funtowicz and Ravetz, 1991, 1994). The aim of this section is to clarify the ways in which research can be 
considered as a collective discourse. Such clarification leads to considering the power issues that arise in the production of discourse.

\subsection{Post-normality, Norms, and Constructivism}

Ecological economics was first created as a forum providing space for criticizing 'normal science,' i.e. science based on an oversimplification of complex issues and aiming at predictions. It also sought to propose an ambitious scientific project by re-embedding science into society, challenging technological paradigms, and seriously considering the issue of the size of the economic scale (Costanza and Daly, 1987). This ambition required a paradigm shift, that is, a revolution in the way knowledge is constructed (Kuhn, 1962). In this sense, the scientific revolution described by Kuhn is a process through which the norms of producing scientific theories or knowledge are questioned and replaced by other norms. For instance, ecological economics considers that knowledge is useful as long as it produces operational solutions, while traditional, positivist science judges the usefulness of knowledge in regard to the accuracy of its predictions (Friedman, 1953).

If we accept the premise that theories are a way to simplify complex realities, then we have to acknowledge that the acceptability of theories or knowledge claims depends on: (i) the ways in which they are communicated within and/or outside the scientific sphere (Luks, 1998) and (ii) the pre-analytical choices and problem-structuring of a given issue (Özkaynak et al., 2002; Giampietro, 2004). To address these two aspects, we must ask a decisive question regarding ontology, i.e. the status that researchers grant to reality. Reality can be either perceived as a something that exists (realism) or something that is constructed (constructivism) - or any blending of these extremes. Answers may vary across disciplines, the subjects under study, or even by researchers. ${ }^{1}$ Constructivists either emphasize the equipment the scientific production process requires (Latour and Woolgar, 1979), the historical determinants of science (Hacking, 2002), or the social effects induced by knowledge production (Hacking, 1999; Daston and Galison, 2007). For constructivists, the structuring of the problem, e.g. establishing categories for analysis, means formatting reality. Moreover, since complexity implies non-equivalent perspectives, choices of narratives have to be made (Allen and Giampietro, 2006). Therefore, theories only tackle a limited set of facets of 'reality.'

Yet moving beyond the split between realism and constructivism, the ways in which science is communicated is also a matter of importance, not only because of the conception of reality it reflects or because of the socio-political effects it induces, but because controlling perceptions about rightness is an issue of power (Martinez-Alier, 2001).

\subsection{What is Academic Discourse (also) About?}

Identifying who (e.g. which peer community) has the ability to design such norms and to which extent they have the power to impose them is therefore crucial because these norms influence the magnitude of theories' acceptance. Indeed, according to Kuhn, the willingness to accept a new scientific theory is not only a question of formal logic. It also depends, maybe to an even greater extent, on its emotional effects and resonance within peer communities (Kuhn, 1957, p.40). In this sense, paradigms not only refer to sets of concepts, theories, and accepted practices within a field of inquiry, but also encompass the entire worldview that this set entails (Kuhn, 1962). It follows, then, that arguing about truth entails arguing about much wider representations of the world. Hence, scientific discourses are not only about producing valid knowledge, but also about power relationships. In other words, discourses not only reflect power relationships or are conceived as a way to make a statement be accepted as truthful, but are also a means to control commonly accepted representations on how the world functions. In this sense, academic discourse, and in particular ecological economics discourse, is rhetoric (Luks, 1998; Shi, 2004).

In ecological economics, some studies have already highlighted questions of power and influence within the field (Røpke, 2005; Spash, 2011). For instance, Røpke (2005) documented the following event at the 1996 conference of ecological economics at Versailles St. Quentin University: during the conference, David Pearce (who at the time was associate editor of the journal 
Ecological Economics) claimed that ecological economics was a sub-discipline of environmental economics. The result was that he had to leave his position on the board of the journal (Spash, 2011, also refers to this event, but noted that "Pearce was not separated from the journal for another two years", p.353). The same sort of censure arose when Cutler Cleveland took over as editor of the journal in 2002. Clive Spash, who had been appointed board member few months before, was dismissed along with others (Røpke, 2005). In some cases, it remains difficult to sort out the reasons why some people were excluded from the field of ecological economics. What we can say with certainty is that not every discourse is (or has been) admissible within ecological economics.

\subsection{Sources of Scientific Discourse}

As these two examples highlight, academic discourses are found primarily in conferences and in academic journals. Such a distinction refers to what Luks (1999) called internal and external rhetoric: internal rhetoric aims at persuading a specific audience (within a scientific community) while external rhetoric aims at convincing a more universal audience (science as a whole, or even the whole world) (Perelman, 1977 introduced this distinction between "persuasion" and "conviction" in the line with the tradition established by Kant and Pascal). ${ }^{2}$ The present study is concerned exclusively with the external discourse of ecological economics for two reasons: (technical and practical reasons are discussed in the next section):

- First, articles present arguments in the most scientific way. They respond to certain codes and norms of presentation (Collins, 1993), while debates in conferences are often more open and may drift to discussing normativity and even the ways science is/should be done. In this study, the purpose is to highlight the differences between fields of scientific production over time, starting with the most 'neutral' method of expression. Journal articles, therefore, enable us to control for the biases of style to some extent.

- Second, the production of articles is much more institutionalized than the debates occurring during conferences. Journals are equipped with a set of rules validating knowledge claims (e.g. articles are examined through the peer-review process). Moreover, there are rules and norms that authors must comply with: the journal's aims and scopes define the admissible topics and the research positioning to be adopted, citing the journal's previous publications is encouraged, final decisions on publication are made by editorial boards, etc. These rules are not only about assessing the truthfulness of papers, but also judging whether or not they comply with the discourse the journal wants to produce. In this regard, they are institutions aiming at controlling discourse.

An interesting feature of the journal Ecological Economics (EE) is that its institutional organization has experienced very few changes since its creation. It is worth noting that the aims and scope of the journal have remained almost unchanged since $1989 .{ }^{3}$ In the same vein, very few changes have occurred among its editors: Costanza was Editor-in-Chief from 1989 to 2002, Cleveland from 2002 to 2007, and Howarth from 2007 to the present. Moreover, the associate editors have remained almost the same through each handover (they remained exactly the same when Howarth took over). The only change of importance that can be noted in the editorial organization of the journal was in 2009, when 19 members were reappointed to the board (Howarth, 2009). ${ }^{4}$ At that time, Stefan Baumgärtner and Sharachandra Lélé replaced Mike Young as Associate Editors (the latter remained in the Editorial Advisory Board of the journal). Finally, another important feature concerns the reviewing process, which is single-blind. In this case, reviewers have access to the identity of the authors. Sometimes, in particular in the early days of the journal, reviewers could choose to reveal their identity, either by signing their reviews or upon the author's request. No clear justification emerges for this choice (Howarth and Spash, personal communication). 


\section{Research and Methods}

Discourse analysis is a useful method for investigating scientific knowledge claims, not only through utterances, that is, the meaning of what is actually written or said (Habermas, 1992), but also concerning the socio-institutional context in which those utterances were made (Harris and Dubois-Charlier, 1969). It enables us to compress the information contained in large numbers of texts and also to situate utterances in regard to the broader context of knowledge production. This section (i) presents the samples used to bring to light EE discourses as well as the encoding variables chosen to tackle the institutional context of discourse production; and (ii) exposes the method used for analyzing the ways in which this discourse has evolved. This method is interdisciplinary by nature and involves blending hermeneutics with the genealogy of discourse production. Textual data treatment facilitated this process, while ensuring the replicability of results.

\subsection{Data Collection and Sampling}

The first hypothesis was that the distance between environmental and ecological economics was decreasing and that disciplinary barriers were tending to fade (Gowdy and Erickson, 2005b; Illge and Schwarze, 2009; Spash and Ryan, 2012). A study by Spash and Ryan (2012) suggests that EE has now become a reference shared by both ecological and environmental economists. Yet, how has the discourse in EE developed in relation to the one prevailing in the environmental economist community? The journals selected for this study cover both communities. In addition to EE, the Journal of Environmental Economics and Management (JEEM) has been identified as the most authoritative outlet for the environmental economist community (Spash and Ryan, 2012). There have been many studies comparing the two journals (Ma and Stern, 2006; Hoepner et al., 2012; Spash and Ryan, 2012; Spash, 2013a).

EE and JEEM are comparable in terms of impact factor. ${ }^{5}$ From the standpoint of discourse production, this means that the discourses produced have similar academic prestige. Nevertheless, there are some significant differences in the number of articles published each year, in particular since the number of issues published per year by EE increased in 2006 (see Figure 1). These differences may cause biases in the discourse analysis. Discourse from EE and JEEM has been complemented with peripheral journals: Environmental Values (EV) for the former and Environmental and Resources Economics (ERE) for the latter, as suggested in Spash and Ryan (2012). To some extent, adding journals to the core journals of the two communities also enables us to distinguish between the discourse produced by ecological economics as a community and the discourse produced within the journal EE (Spash, 2013a).

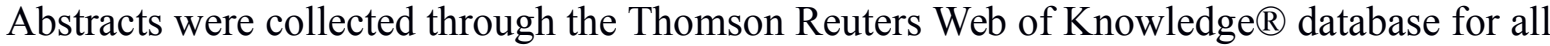
the years available (1994-2013). Before 1994 and for the last issues published but not yet referenced in the database, or when the journal was missing from the Web of Knowledge ${ }^{\circledR}$ database, abstracts were collected via the concerned journal's website. The time frame was set from 1989 when the journal EE was created up to December 2013. Recurring errors have been detected in the abstracts of ERE between 2000 and 2004 (4 to 8 spaces were missing in some of the words in the abstracts). These errors have been manually corrected.

Abstracts were then compiled into a single textual corpus (see Appendix A). Variables have been added in order to identify the year of the journal's publication (variable PY, subvariables are the years from 1989 to 2013) and the name of the publication (variable SO, categories EE, JEEM, EV, and ERE). 6,237 abstracts were analyzed. Over the entire period, 58\% of the abstracts were from ecological economics and $41 \%$ from environmental economics. Figure 1 displays the number of abstracts analyzed for each journal between 1989 and 2013. 


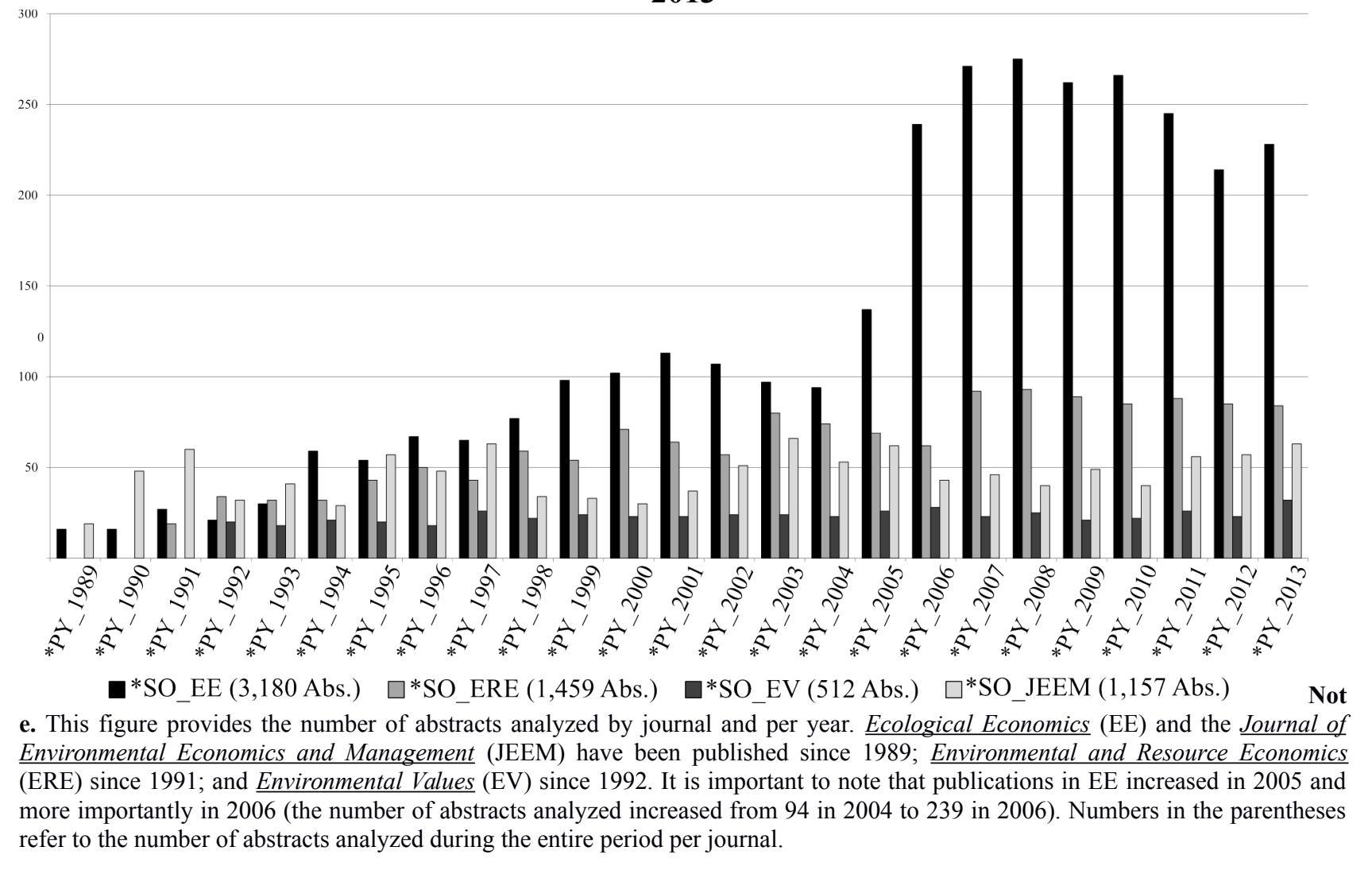

\subsection{Methods and Results}

Analyzing discourse produced while accounting for its complexity requires using multiple methods (Norgaard, 1989; Costanza et al., 1997a). Of course, these methods need to share the same basic ontologies (Ahmed and Sil, 2012; Spash, 2012). Here, I combine a hermeneutic of statistical treatment of texts with an historical approach to discourse production. These methods used in this way are consistent with the constructivist perspective of science endorsed in Section 2. Indeed, scientific discourses are not produced in a vacuum. On the one hand, they take place in a context of editorial choices and are influenced by prevailing social conventions of what valuable knowledge production is for a journal (e.g. knowledge that will increase the Impact Factor of a given journal). On the other hand, academic discourse evolves over time, which means that valuable knowledge is also influenced by socio-historical factors and contingent societal concerns (e.g. climate change, ecosystem services).

Analyzing textual content to such an extent may be difficult, or at least require a large amount of resources (for instance, see Luzadis et al., 2010, for a laborious content analysis of a survey of 200 articles published in EE). The method of textual statistics used here compresses the information contained in large texts in such a way that it can be more easily interpreted (Reinert, 1983; Benzécri, 1992; Lebart and Salem, 1994). I then used (i) correspondence analysis (Benzécri, 1992), and (ii) a descendant classification (Reinert, 1983) to obtain visual representations that put the main information to be analyzed into a form. More fundamentally, these two methods allow results to be replicable, which is definitely a problem in qualitative studies (Dafoe, 2014; Ishiyama, 2014). Data processing was facilitated by the use of two tools: Alceste software has been developed along the lines of Max Reinert's research, which initiated the method of descendant classification (Reinert, 1983, 1990); and Iramuteq, which has recently been developed on a R basis, reproducing the original Alceste algorithm and displaying complementary statistical information (Ratinaud and Dejean, 2009). ${ }^{6}$

These two methods (correspondence analysis and hierarchical classification) proceed from 
conventional statistics applied to the root-words used in texts and in particular to multivariate data processing. Forms of words (such as infinitive forms of verbs or the singular for common names) are characterized as an interrupted chain of signs (i.e. letters, or numbers, but not punctuation) in order to be automatically processed. ${ }^{7}$ A supplementary variable has been introduced to distinguish ecological from environmental economics discourse (variable name is Type, and subvariables are Ecol for ecological economics discourse and Env for environmental economics discourse). From this set of variables, two have been created to account for both the arena of discourse production (i.e. the type of journal) and the year of production: the DistType variable refers to the text published by a type of journal at some point in time (subvariables are Ecol1989, Ecol1990, Ecol19991... to Econ2012, and Econ2013, in all, 50 subvariables). The Dist variable refers to the text published in a journal at a given point of time (modalities are EE1989, EE1990..., EV1992, EV1993... ERE1991, ERE1992, to JEEM2012, and JEEM2013, 95 subvariables in all). Correspondence analysis and hierarchical classification together enable us to link discourses (statistically understood as a group of forms of words) to variables.

\section{Evolution of EE Discourse}

The results obtained by correspondence analysis and hierarchical classification are presented in the two following sub-sections. They suggest that (i) ecological and environmental economics have tended to move closer over time and that (ii) ecosystem services valuation methods and debates are increasing over time.

\subsection{How have the Ecological and the Environmental Economics Discourses Coevolved?}

Correspondence analysis has been used to analyze the entire corpus in regards to the two variables DistType (the evolution of the distance between communities - Figure 2a.) and Dist (the evolution of the distance between journals - Figure 2b.). The aim was to see how the ecological and environmental economics discourses have coevolved since 1989 and how the core journals (EE and JEEM) compared with peripheral journals (EV and ERE) in these trends.

Correspondence analysis proceeds from a matrix where forms of words are placed in rows and variables are placed in columns. Proportions of occurrences of forms in relation to a given subvariable are then evaluated through a chi-square test. The variability of the data assessed as a chi-square value is then statistically explained by inertia. The correspondence analysis graph then displays the distance between the subvariables of a given variable according to the vocabulary that is significantly associated with each subvariable. Figures $2 \mathrm{a}$ and $2 \mathrm{~b}$ display the representations for factor $1(27.01 \%$ of the inertia) and $2(22.60 \%$ of the inertia) of the variability in the DistType (the evolution of the distance between communities) and the Dist (the evolution of the distance between journals) variables (respectively). Here, the meaning of the factor provided by the variability of the forms of words making up discourses is not fundamentally relevant. Indeed as the information contained in the 6,308 abstracts is substantially compressed (half of the inertia is explained by two factors), the meaning of the factors is necessarily imprecise (Appendix $\mathrm{C}$ displays the distribution of the vocabulary according to the two main axes, which enables us to interpret the factors explaining the variability of discourse and variables: from theoretical-conceptual to methodological concerns for factor 1; from the description of empirical domains to scientific vocabulary for factor 2). The aim is rather to characterize the coevolution of the two fields of ecological and environmental economics and deconstruct this coevolution according to the core journals of these fields.

Figure 2a suggests that (i) environmental economics is evolving from year to year, from assessing preferences through willingness to pay to analyzing market devices for environmental management, in particular in the agricultural sector; (ii) ecological economics is evolving from a very specific position (defining and circumscribing the field of ecological economics) to biodiversity assessment and management; and (iii) that ecological economics is drifting toward environmental economics, while the opposite does not seem to be the case. Figure $2 \mathrm{~b}$ suggests that (i) environmental economists have a much more unified discourse than ecological economists, (ii) 
EE explains most of the variability of the evolution in the ecological discourse, and (iii) in the most recent period, EE is relatively close to the environmental economics discourse.

Figure 2. Coevolution of the Discourses in Ecological and Environmental Economics, 19892013

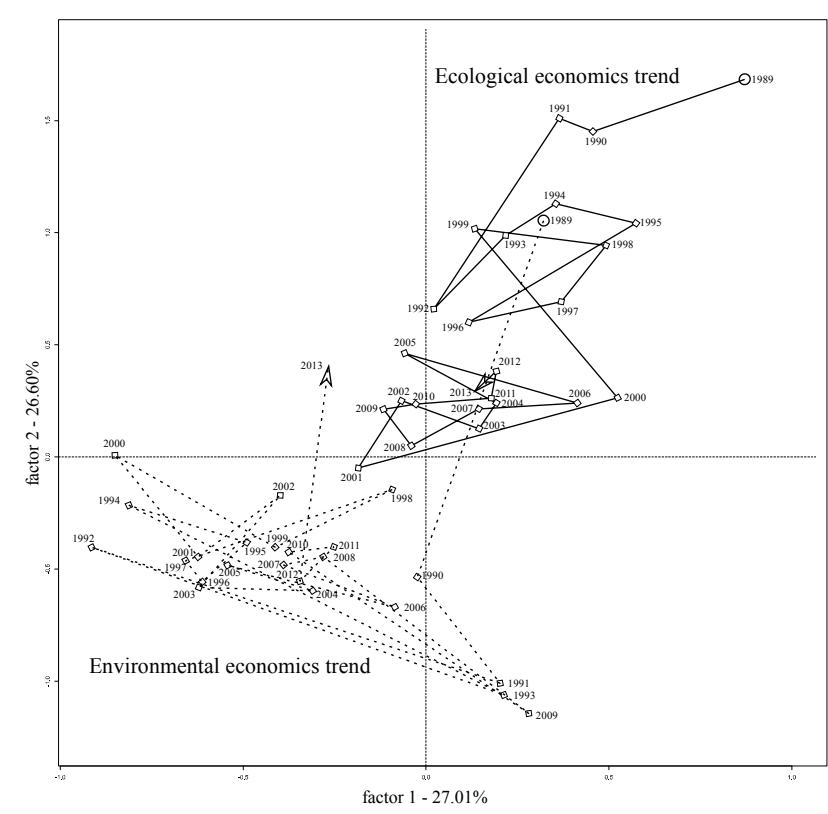

Figure 2a. Coevolution of the communities' discourses

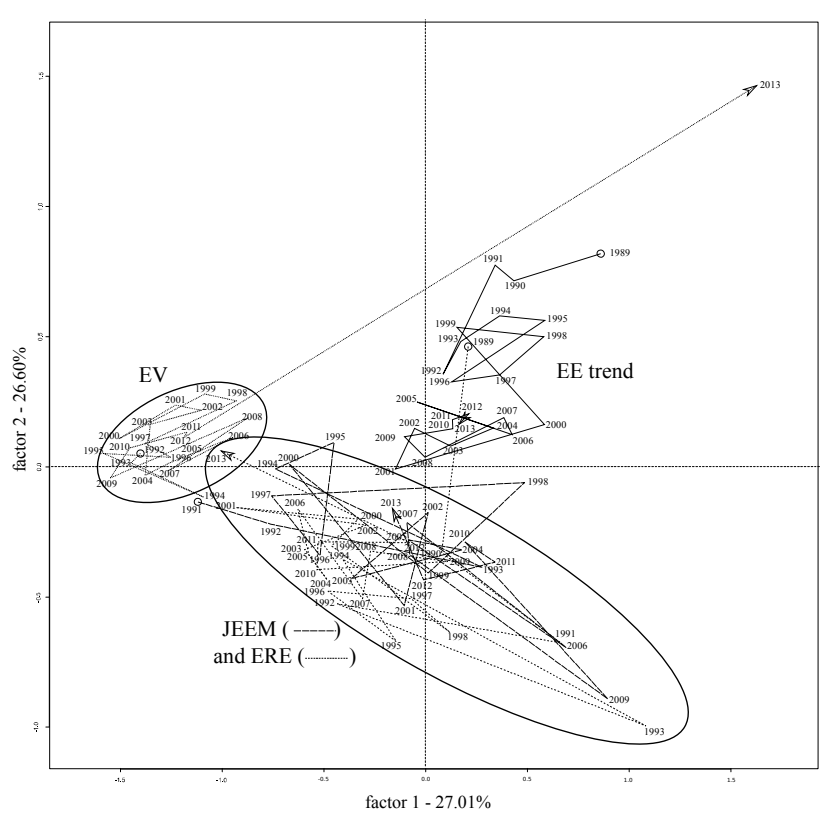

Figure 2b. Coevolution of the four journals' discourses Note. Figures $2 \mathrm{a}$ and $2 \mathrm{~b}$ represent the variability of the variables (respectively DistType and Dist) according to the vocabulary representative of each subvariable. They display the distance of the subvariables for each variable. Each subvariable has then been linked chronologically. Trends in Figure $2 \mathrm{a}$ are built from averaging the two composing trends of Figure $2 \mathrm{~b}$ (i.e. ERE and JEEM for the environmental economics pattern and $\mathrm{EV}$ and $\mathrm{EE}$ for the ecological economics one).

\subsection{How has Ecological Economics' Discourse Evolved?}

The aim of the descendent classification was to analyze the evolution of the discourse produced in the journal. For this purpose, analyses were conducted on the sub-corpus of the 3,162 EE abstracts only. Abstracts and forms (lemmatized forms of words) were placed in a matrix counting the number of times a form (placed in a row) appeared in an abstract (in columns). The proportions of occurrences of forms in abstracts were then calculated. An algorithm of computation (Ratinaud and Marchand, 2012) was then applied to the matrix to obtain a grouping of abstracts that were highly contrasted in terms of the repartition of forms (i.e., two groups of abstracts with very few overlapping forms are obtained). A chi-square test was then calculated for every possible subdivision of these groupings. The most significant classification of forms contained in the grouping of abstracts was retained. The chi-square value was calculated on forms, variables, and abstracts. The significance threshold of the chi-square test was set at 3.84, which means that there is a $0.05 \%$ chance that a correspondence between forms, variables, or abstracts and a class of words contained in the abstracts is random.

Descendant classifications have been constructed to define a supplementary variable ( $\mathrm{P}$ was set as a period variable, grouping several years of publication): instead of an abstract, columns exhibited subvariables of the variable (first period, second period) and emphasized the most significant vocabulary for every period. The definition of periods followed a trial and error process. Several classifications were constructed with different groupings of years that were similar in terms of the number of abstracts published. Finally, the most meaningful classification was retained for 7 periods (i.e. 7 subvariables for the variable P). Figure 3 displays the final classification used.

In the classification, a given form is not meaningful in itself, but should be analyzed in terms of the semantic context (i.e. the class of forms) in which it has been used. The other forms of the class can provide indications about the ways in which a given form has been used. Theoretically, if a single form is used in two different contexts, it should appear in two separate classes. This should 
solve the problem of positive or negative use of a form (e.g. monetary valuation being used as a tool for revealing preferences or being criticized as a concept). Given the level of compression of information (because of the amount of text analyzed), I suspected this condition was not fulfilled, and then collected the most significant abstracts of each period. Representative references (in chisquare terms) are summarized in Table 2 to provide a clearer direction on the use of the terms (for example, when the form $\underline{w t p}$ was significantly used in a given period, was it used for the same purpose as in other periods?).

Table 1 - Descendent Classification: Evolution of the Ecological Economics Discourse 19892013

\begin{tabular}{|c|c|c|c|c|c|c|c|c|c|c|c|c|c|c|c|c|c|c|c|c|}
\hline \multicolumn{3}{|c|}{ 1989-1999 } & \multicolumn{3}{|c|}{$2000-2002$} & \multicolumn{3}{|c|}{ 2003-2005 } & \multicolumn{3}{|c|}{ 2006-2007 } & \multicolumn{3}{|c|}{ 2008-2009 } & \multicolumn{3}{|c|}{$2010-2011$} & \multicolumn{3}{|c|}{$2012-2013$} \\
\hline FORMS & Chi2 & $\%$ & FORMS & Chi2 & $\%$ & FORMS & Chi2 & $\%$ & FORMS & Chi2 & $\%$ & $\begin{array}{l}\text { FORMS } \\
\end{array}$ & Chi2 & $\%$ & FORMS & Chi2 & $\%$ & $\begin{array}{l}\text { FORMS } \\
\end{array}$ & Chi2 & $\%$ \\
\hline econom & 97 & $22 \%$ & woodland & 73 & $54 \%$ & breed & 105 & $49 \%$ & disaster & 33 & $53 \%$ & appropri & 42 & $51 \%$ & pes & 70 & $49 \%$ & heterogeneit & 42 & $35 \%$ \\
\hline sustain & 53 & $23 \%$ & copper & 57 & $46 \%$ & genetic & 54 & $40 \%$ & ntfp & 29 & $56 \%$ & percent & 28 & $27 \%$ & coevolution & 42 & $62 \%$ & resili & 37 & $40 \%$ \\
\hline ecolog & 49 & $24 \%$ & wetland & 25 & $23 \%$ & biolog & 35 & $24 \%$ & there & 21 & $23 \%$ & biomas & 23 & $36 \%$ & ecosystem_serv & 26 & $25 \%$ & climate & 28 & $23 \%$ \\
\hline ethic & 48 & $58 \%$ & land & 22 & $15 \%$ & abatement & 34 & $25 \%$ & account & 19 & $23 \%$ & case & 23 & $25 \%$ & location & 24 & $34 \%$ & cities & 24 & $34 \%$ \\
\hline natural & 47 & $25 \%$ & count & 21 & $25 \%$ & divers & 31 & $25 \%$ & car & 18 & $43 \%$ & dairy & 22 & $50 \%$ & $\operatorname{logit}$ & 23 & $40 \%$ & findings & 23 & $24 \%$ \\
\hline preservation & 40 & $41 \%$ & $\mathrm{~km}$ & 19 & $32 \%$ & extinct & 22 & $34 \%$ & service & 18 & $24 \%$ & yr & 22 & $57 \%$ & china & 22 & $29 \%$ & infrastructure & 22 & $33 \%$ \\
\hline entropy & 39 & $53 \%$ & ha & 19 & $25 \%$ & species & 21 & $18 \%$ & data & 17 & $22 \%$ & water & 20 & $24 \%$ & justice & 22 & $43 \%$ & invest & 21 & $22 \%$ \\
\hline environ & 39 & $27 \%$ & nature & 17 & $18 \%$ & cost & 20 & $15 \%$ & method & 17 & $22 \%$ & result & 19 & $21 \%$ & irrigation & 21 & $35 \%$ & innovation & 20 & $26 \%$ \\
\hline thermodynamic & 39 & $45 \%$ & simul & 17 & $21 \%$ & motive & 19 & $34 \%$ & cover & 16 & $28 \%$ & ef & 17 & $34 \%$ & help & 19 & $26 \%$ & norm & 19 & $31 \%$ \\
\hline neoclassical & 38 & $39 \%$ & stream & 16 & $29 \%$ & sharing & 19 & $28 \%$ & freshwater & 16 & $43 \%$ & year & 17 & $25 \%$ & origin & 19 & $36 \%$ & transact & 19 & $28 \%$ \\
\hline argument & 33 & $40 \%$ & despite & 15 & $21 \%$ & table & 19 & $32 \%$ & migration & 15 & $39 \%$ & hydrolog & 16 & $42 \%$ & scheme & 19 & $27 \%$ & find & 17 & $18 \%$ \\
\hline develop & 32 & $21 \%$ & valuation & 14 & $16 \%$ & multiple & 18 & $21 \%$ & inform & 13 & $22 \%$ & climate & 14 & $25 \%$ & reveal & 18 & $26 \%$ & ecosystem_serv & 17 & $20 \%$ \\
\hline resource & 32 & $22 \%$ & flow & 13 & $17 \%$ & technolog & 18 & $17 \%$ & valuation & 13 & $23 \%$ & wtp & 14 & $19 \%$ & emerg & 17 & $29 \%$ & our & 17 & $19 \%$ \\
\hline problem & 31 & $24 \%$ & section & 13 & $25 \%$ & predator & 17 & $32 \%$ & measur & 12 & $30 \%$ & eco & 14 & $31 \%$ & biofuel & 16 & $44 \%$ & game & 16 & $30 \%$ \\
\hline his & 31 & $50 \%$ & pay & 12 & $19 \%$ & wildlife & 17 & $24 \%$ & province & 12 & $37 \%$ & average & 13 & $27 \%$ & cooperat & 16 & $28 \%$ & challenge & 15 & $22 \%$ \\
\hline environmental & 28 & $20 \%$ & concentr & 12 & $22 \%$ & basi & 15 & $19 \%$ & border & 11 & $36 \%$ & basin & 13 & $32 \%$ & effect & 16 & $19 \%$ & framework & 15 & $19 \%$ \\
\hline must & 28 & $31 \%$ & ecosystem & 12 & $15 \%$ & program & 15 & $18 \%$ & derive & 10 & $31 \%$ & occurr & 13 & $37 \%$ & payment & 15 & $25 \%$ & auction & 14 & $37 \%$ \\
\hline concept & 27 & $26 \%$ & waste & 12 & $19 \%$ & watershed & 15 & $24 \%$ & manage & 10 & $20 \%$ & socioeconomic & 13 & $35 \%$ & common & 14 & $23 \%$ & boundaries & 14 & $31 \%$ \\
\hline system & 26 & $22 \%$ & ask & 11 & $24 \%$ & invasive & 14 & $27 \%$ & state & 10 & $21 \%$ & agent & 11 & $29 \%$ & establish & 14 & $25 \%$ & deliver & 14 & $30 \%$ \\
\hline ecologically & 25 & $39 \%$ & local & 11 & $15 \%$ & livestock & 14 & $22 \%$ & desire & 9 & $33 \%$ & financial & 11 & $28 \%$ & percent & 14 & $22 \%$ & exposure & 14 & $37 \%$ \\
\hline $\operatorname{man}$ & 25 & $42 \%$ & ekc & 10 & $20 \%$ & plant & 14 & $18 \%$ & dutch & 9 & $34 \%$ & river & 11 & $29 \%$ & select & 14 & $24 \%$ & substitut & 14 & $26 \%$ \\
\hline ocean & 25 & $46 \%$ & timber & 10 & $19 \%$ & wild & 14 & $31 \%$ & magnitude & 9 & $29 \%$ & uk & 11 & $32 \%$ & eu & 13 & $29 \%$ & urban & 14 & $22 \%$ \\
\hline long & 24 & $25 \%$ & appear & 9 & $17 \%$ & wood & 14 & $25 \%$ & vehicle & 9 & $33 \%$ & fossil & 10 & $30 \%$ & farmers & 13 & $30 \%$ & identify & 13 & $21 \%$ \\
\hline view & 24 & $27 \%$ & hectare & 9 & $25 \%$ & biodiversi & 13 & $17 \%$ & criteria & 8 & $25 \%$ & group & 10 & $24 \%$ & insight & 13 & $26 \%$ & chain & 12 & $26 \%$ \\
\hline rate & 22 & $24 \%$ & kyoto & 9 & $22 \%$ & as & 13 & $13 \%$ & full & 8 & $25 \%$ & high & 10 & $21 \%$ & invasive & 12 & $31 \%$ & communic & 12 & $28 \%$ \\
\hline
\end{tabular}

Note. This descendent classification provides the most representative vocabulary (list of forms) associated to each period for the EE corpus between 1989 and 2013. The chi-squared value assesses the significance of the association between a form (lemmatized words) and the vocabulary used in a given period (chi-squared value 3.84 corresponds to a $0.05 \%$ chance of random association). Usually, significance is linked to the presence of the vocabulary in a given period, but rarely a form often associated with a given vocabulary may be associated to the period it is less frequently used in, despite appearing more often in the rest of the abstracts. To account for this phenomenon, the percentage of a form's presence in a given period is provided. For instance, the most representative form in the first period is econom (lemmatized form of economic). $22 \%$ of the occurrences of this form appear in the first period. Forms in bold refer to issues valuation and ecosystem services.

The vocabulary used to construct each period and the significant abstracts for each period enable us to interpret EE's contribution to ecological economics discourse over time:

- The first period (1989-1999): EE contributed to conceptualizing the field of ecological economics (concept, sustainability). ${ }^{8}$ This discourse formed the basis of the intellectual influences of the movement. Concepts borrowed from

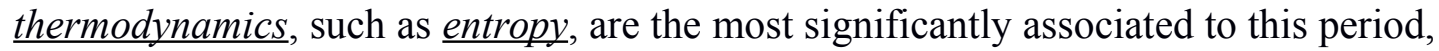
which is also marked by references to neoclassical economics, to differentiate from it but also to contribute to it (Table 2).

- In the second period (2000-2002), studies published in EE are most significantly empirical. Here, the goal was not conceptualizing, but applying concepts such as sustainability. In this period, ecological disciplinary views seem to prevail (Table 2), and the need for assessment (valuation) of the role of the ecosystem and in certain areas, environmental regulation, was brought to the fore $(\underline{\mathrm{km}}, \underline{\mathrm{ha}})$.

- In the third period (2003-2005), EE's discourse focused on biodiversity issues as representative of the under-representation of the ecosystem in decision-making processes, and in particular in the agricultural sector. It is important to note that economic vocabulary is not significantly associated to the discourse prevailing in this period.

- The fourth period (2006-2007) is oriented towards deciding on methodologies to account for the hidden processes of ecosystems, and in particular to providing scientific measures of natural phenomenon. In this period, no unquestioned criterion 
on which to base evaluation is imposed, but valuation increases as a conventional tool for management.

- In the fifth period (2008-2009), economic valuation, in particular through wtp, is used jointly with biophysical indicators such as ecological footprint ( $\underline{e f}$ ) and net primary product $(\underline{n p p})$. The most significant issues of the period are water (hydrology, river) and energy ( biomass, fossil).

- In the sixth period (2010-2011), market instruments of regulation, such as pes, are analyzed (also from a justice perspective), as well as constructed (Table 2). Preferences are not only assessed through wtp (as was the case primarily in the previous period), but also revealed in actual payment. It is important to note that $\mathrm{EE}$ not only analyzed such processes, but also contributed to imposing them (Söderbaum, 2013). This trend relied on and contributed to the notion of ecosystem services.

- The seventh period (2012-2013) is marked by ecological economics concepts (resilience) and very general issues (climate). Though the trend is less obvious than in the previous period, the notion of ecosystem services is still very present.

Moreover, Table 2 suggests that the significance of the vocabulary displayed in Table 1 may be underestimated. Indeed, the most representative references of the discourse production in the last two periods (since 2011) all discuss and/or apply valuation techniques. Most of them use money as the valuation metric. 


\section{Table 2 - Most Significant References Published in Ecological Economics for each Period between 1989 and 2013}

\begin{tabular}{l} 
Reference \\
\hline Van Den Bergh, J.C.J.M. and Nijkamp, P. 1991, Operationalizing sustainable development: dynamic ecological \\
economic models, 4(1): 11-33. \\
Cleveland, C. 1993, An exploration of alternative measures of natural resource scarcity: the case of petroleum \\
resources in the U.S., 7(2): 123-157. \\
Bateman, I.J., Langford, I.H., Turner; R.K., Willis, K.G. and Garrod, G.D. 1995, Elicitation and truncation effects in \\
contingent valuation studies, 12(2): 161-179. \\
Scatena, F.N., Walker, R.T., Homma, A.K.O., de Conto, A.J., Palheta Ferreira, C.A., Carvalho, R.A.; Neves da Rocha, \\
A.C.P., Moreira dos Santos, A.I. and Mourao de Oliveira, P. 1996. Cropping and fallowing sequences of small farms in \\
the "terra firme" landscape of the Brazilian Amazon: a case study from Santarem, Para. 18(1): 29-40. \\
Prato, T. 2001, Modeling carrying capacity for national parks, 39(3): 321-331. \\
Binswanger, M. 2001, Technological progress and sustainable development: what about the rebound effect?, 36(1): \\
119-132. \\
Campbell, B.M., Dore, D., Luckert, M., Mukamuri, B. and Gambiza, J. 2000, Economic comparisons of livestock \\
production in communal grazing lands in Zimbabwe, 33(3): 413-438. \\
Gerbens-Leen, P.W., Moll, H.C. and Schoot Uiterkamp, A.J.M. 2013, Design and development of a measuring
\end{tabular}

Gerbens-Leenes, P.W., Moll, H.C. and Schoot Uiterkamp, A.J.M. 2013, Design and development of a measuring method for environmental sustainability in food production systems, 46(2): 231-248.

Spatari, S., Bertram, M., Gordon, R.B., Henderson K. and Graedel, T.E. 2005, Twentieth century copper stocks and flows in North America: A dynamic analysis, 54(1): 37-51.

Simianer, H. 2005, Decision making in livestock conservation, 53(4): 559-572.

Martínez, M.L., Intralawan A., Vázquez G., Pérez-Maqueo; O., Sutton, P. and Landgrave, R., 2006, The coasts of our world: Ecological, economic and social importance, 63(2-3): 254-272.

de Haan, P., Mueller, M.G. and Peters, A. 2006, Does the hybrid Toyota Prius lead to rebound effects? Analysis of size and number of cars previously owned by Swiss Prius buyers, 58(3): 592-605.

Lowell, K., Drohan, J., Hajek, C., Beverly, C. and Lee, M. 2007, A science-driven market-based instrument for determining the cost of environmental services: A comparison of two catchments in Australia, 64(1): 61-69.

Tsuzuki, Y., 2008, Relationships between water pollutant discharges per capita (PDCs) and indicators of economic level, water supply and sanitation in developing countries, Ecological Economics, 68(1-2): 273-28.

Parra-López, C., Groot, J.C.J., Carmona-Torres, C. and Rossing, W.A.H. 2008, Integrating public demands into modelbased design for multifunctional agriculture: An application to intensive Dutch dairy landscapes, 67(4): 538-551 .

Hunt, C. 2007, Economy and ecology of emerging markets and credits for bio-sequestered carbon on private land in tropical Australia, 66(2-3): 309-318.

Cave, L.A. and Blompist, G.C. 2008, Environmental policy in the European Union: Fostering the development of pollution havens?, 65(2): 253-261.

Lauk, C. and Erb, K.H. 2009, Biomass consumed in anthropogenic vegetation fires: Global patterns and processes, 69(2): 301-309.

Bussoni, A.G. and Estraviz, L.C. 2010, Private valuation of carbon sequestration in forest plantations, 69(3): 451458.

Hanley, N., Czajkowski, M., Hanley-Nickolls, R. and Redpath, S. 2010, Economic values of species management options in human-wildlife conflicts: Hen Harriers in Scotland, 70(1): 107-113.

Daniels, A.E., Bagstad, K., Esposito, V., Moulaert, A. and Rodriguez, C.M. 2010, Understanding the impacts of Costa Rica's PES: Are we asking the right questions?, 69(11): 2116-2126.

Tianhong, L., Wenkai, L. and Zhenghan, Q. 2010, Variations in ecosystem service value in response to land use changes in Shenzhen, 69(7): 1427-1435.

Vatn, A. 2010, An institutional analysis of payments for environmental services, 69(6): 1245-1252.

Mendoza-González, G., Martínez, M.L., Lithgow, D., Pérez-Maqueo, O. and Simonin, P. 2012, Land use change and its effects on the value of ecosystem services along the coast of the Gulf of Mexico, 82: 23-32.

Humphries, S., Holmes, T.P., Kainera, K., Gonçalves Kouryd, C.G., Cruze, E. and de Miranda Rocha, R. 2012, Are community-based forest enterprises in the tropics financially viable? Case studies from the Brazilian Amazon, 77: 6273.

Voltaire, L., Pirrone, C. and Bailly, D. 2013, Dealing with preference uncertainty in contingent willingness to pay for a nature protection program: A new approach, 88: 76-85.

Lawn, P. 2013, The failure of the ISEW and GPI to fully account for changes in human-health capital - A methodological shortcoming not a theoretical weakness, 88: 167-177.

Henrik Ernstson, H. and Sörlin, S. 2013, Ecosystem services as technology of globalization: On articulating values in urban nature, 86: 274-284.

Period
$1989-1999$$\frac{\text { Chi2 }}{30}$

1989-1999 $\quad 30$

1989-1999 30

1989-1999 $\quad 30$

$\frac{}{2000-2002} \frac{}{60}$

2000-2002 51

2000-2002 51

2003-2005

2003-2005 48

2003-2005 $\quad 48$

2006-2007 34

2006-2007 30

$\frac{2006-2007}{2008-2009} \frac{30}{27}$

2008-2009 27

$2008-2009 \quad 27$

2008-2009 27

$\underline{2008-2009} \stackrel{27}{2}$

2010-2011 26

$2010-2011 \quad 21$

$2010-2011 \quad 21$

$2010-2011 \quad 21$

2010-2011 21

2012-2013 25

$2012-2013 \quad 25$

2012-2013 25

2012-2013 25

$2012-2013 \quad 25$

Note. Table 2 displays the most representative abstracts of each period defined in Table 1. A chi-square test was calculated on the proportion of words contained in the abstracts vs. the proportion of words contained in other abstracts of other periods. The significance threshold was set to a chi-square value of 3.84 , for which there is a $0.05 \%$ chance that the association between a given abstract and a given period is random. 


\section{Discussion: How Pragmatism Shapes the Language of Ecological Economics}

Results drawn from textual analysis seem to indicate (i) a tendency of EE to move closer to the discourse produced in the field of environmental economics (Figures 2), and (ii) the co-emergence of the notion of ecosystem services on the one hand, and the resort to monetary valuation techniques on the other hand (Tables 1 and 2). In this section, I present the hypothesis that the adoption of a pragmatic position within the community is causing the double trend described in Section 4.

\subsection{The Creation of a Favorable Context}

Three elements provide a favorable context for this trend to occur: the mechanisms for attracting mainstream economists within the community; the editorial policy of the journal EE; and a shift in the stance of the most influential ecological economist, Robert Costanza.

The first clue lies in the coexistence, within ecological economics, between mainstream economists and heterodox economists. Røpke $(2004,2005)$ even emphasizes that in the early $90 \mathrm{~s}$, the mainstreaming of ecological economics was a conscious strategy. The latter developed innovative methods, theories and scientific practices in order to develop inventive solutions, while the former had the power to impose a particular political agenda. The results highlighted in the textual analysis in Section 4 reflect this phenomenon. On the one hand, we can see a growing plurality in the concepts, methods (including valuation methods), issue-areas, and so forth appearing in EE discourse (in Table 1, words appearing in one period are often not present in the previous or following periods). On the other hand, the barriers between ecological and environmental economics - at least for some dimensions - seems to become blurred (see Figures 2).

To some extent, the editorial policy of the journal is permeated with this strategy. First, increasing the number of articles published each year (see Figure 1) promoted a diversity of narratives and languages within EE, but also opened the journal more broadly to environmental economists. Røpke (2005, p.271) thus noted that mainstream economists "became increasingly visible in the journal, especially when the number of issues was increased from 1994." Second, by seeking (and succeeding) to increase the academic prestige of the journal, editorial policy opened a wide and attractive space for scholars interested in combining environmental and socio-economic concerns, and for multiple viewpoints and perspectives that have enriched the field over the years. In the 'publish or perish' academic context, publishing in EE appears all the more desirable for an increasing number of scholars. In 2008, roughly 700 papers were submitted (Howarth personal communication), whereas in 2013, more than 1100 papers were submitted to EE (calculated from the acceptance rate published by the Elsevier Website). While the proportion between mainstream and heterodox economists may have remained unchanged compared to the early days of the journal, in absolute terms, mainstream vocabulary appears more significant in the textual analysis (irrespective of how this vocabulary may have evolved over time).

The final clue can be seen in the career-path of Robert Costanza, the leading and founding member of the International Society for Ecological Economics and of the journal Ecological $\underline{\text { Economics }}$ (he was also its first Editor-in-Chief until 2002) and probably the most influential author in the EE field and the journal. He was trained as an Aerospace Engineer (1968-1970), received a BA in Architecture (1973), an MA in Architecture/Urban and Regional Planning (1973), and finally a Ph.D. in Systems Ecology, Environmental Engineering Sciences with a minor in Economics (1979). ${ }^{9}$ His supervisor was Howard T. Odum, a complex system ecologist who applied entropy flow to account for the energy appropriation of systems (e.g. Odum, 1996). Costanza's early works (Costanza, 1980) were in line with energy analysis, but slowly evolved to ecosystem services monetary valuation (Costanza et al., 1997b may be seen as a significant turning point). The congruence of these two trajectories indicates the influence Costanza had (Røpke, 2005; Spash, 2011) and still seems to have over the editorial choices of EE, and more broadly, on the field. 


\subsection{The Risks of Pragmatism}

Costanza's career path can then be used to approach the trends observed in EE (e.g. Anderson and M'Gonigle (2012) refer to Costanza's positions in regards to Stern's report on climate change to establish a hypothesis on broader approaches used in the field of ecological economics). Deconstructing the mechanisms by which a system of influence remains in scientific production would take us beyond the scope of this paper - although such a study would be of major interest. Rather, this paper focuses on the justifications behind such choices, which have since been constructed as a social convention among many ecological economists and beyond. The reason for this turn in research, Costanza explained, was to shape a language that would influence political decisions quickly and in a decisive way. Similarly, the notion of ecosystem services was coined as a metaphor to appeal to public opinion (Norgaard, 2010). Spash (2009, 2011, 2012, 2013b) termed this approach 'New Environmental Pragmatism': "the most important role for research is to be pragmatic and employ whatever approaches are effective to inform the policy community about environmental problems and their solution" (Spash and Ryan, 2012, p.1101, authors' emphasis). Although there is a lack of consensus on this approach at the community level (Douai and Vivien, 2009; Spash and Ryan, 2012), increasing references to ecosystem services through a monetary valuation perspective can be interpreted as a sign that New Environmental Pragmatism is growing within ecological economics. This idea is further supported by Costanza's justifications of his research orientations, as well as his judgments on the use of neoclassical economics methodologies. Anderson and M'Gonigle (2012) thus noted that "Costanza's review of Stern's strategy [of the carbon trade price market] points to a contradiction at the core of ecological economics, a contradiction between mainstream means and heterodox ends, with a confused space in between" (p.39). This "contradictory and confused space" is probably the price of combining pragmatism and pluralism.

It would be useful to assess the extent to which ecological economists contributed to this context of academic pragmatism beyond the scope of ecological economics itself, and how it contributes to blurring the frontier between mainstream orthodox economists and heterodox economists. Here, I merely point out the fact that there is common ground between environmental and ecological economics, persisting over time in EE, which I interpret as influenced by the increase of the pragmatist approach. This common ground expresses itself by the use (and maybe the co-construction) of a common language. The results presented here seem to suggest that opening up to the language of monetary valuation and ecosystem services serves the pragmatic purposes of academics by weighing on decision-making (Norgaard, 2010, Barnaud and Antona, 2014). However, "the language of the New Environmental Pragmatists is one of the market place, accountants, financiers and bankers" (Spash, 2009, p.256). This may be problematic since the increasing use of a given language outlines the beliefs and representations of a community. Journals are a fundamental tool for shaping this language, as Anderson and M'Gonigle (2012) suggest in the case of climate change. Moreover, the choice of a particular type of valuation can be interpreted as a way to impose a particular representation of the world (Martinez-Alier, 2003). Of course, I am not suggesting that this "implicit acceptance of the hegemony of mainstream economic methodologies," as addressed by Anderson and M'Gonigle in their abstract (2012, my emphasis) is voluntarily shaping language to exclude other ways of framing problems and envisioning solutions. The convergence described in Section 4 may not appear as a convergence of a shared or overlapping problem domain, nor as a tacit agreement on monetary techniques. It can also be viewed as the result of a kind of language imposing itself as a convention enabling communication, debates and even critiques to take place among communities and within ecological economists, but on a register that is far from being neutral.

\section{Conclusions: Where do We Go from Here?}

This paper retraces the evolution of EE's publications and concludes that it has drifted toward environmental economics and an increasing use of ecosystem services valuation as a way to influence political decisions. I have suggested that this 'pragmatic' position is largely shared by 
environmental researchers at large, which is contributing to establishing ecosystem monetary valuation as a social convention among environmental researchers. As a result of the journal's policy to broaden the kinds of articles it publishes, this language is increasing in EE, whether this language is to be applied, to be criticized, or to be questioned. Finally, the primary goals of the community, and in particular that of methodological pluralism, have led the second generation of ecological economists to face the fundamental risk of producing and reproducing a language that, if this trend continues, may reduce the plurality of viewpoints and possibly exclude valuable solutions for environmental problems. The restriction of language may also effect more than ecological economics, since pragmatism can be compatible with both the post-normality set as a foundation of ecological economics and the positivism prevailing in neoclassical economics (and environmental economics in particular). The conundrum we - as ecological economists - have to solve, is that of the extent to which we agree to pursue this path even though it may reduce plurality (and which kind of plurality) within the field, as well as in the production of knowledge for a more sustainable development. This problem also raises the question of the collective identity of ecological economists. I have tackled this collective identity issue by analyzing abstracts published in EE as representative of the evolution of ecological economics discourse. This approach has led to clear results, though it tells us little about ecological economists themselves. For instance, the reasons why authors refer to ecosystem services valuation may differ, and a line must be drawn between research studying or criticizing monetary valuation from those simply applying the valuation of ecosystem services without questioning its methods and concepts.

Paradoxically, one way out of this conundrum lies in the very pragmatism the early ecological economists adopted as a strategy for the community, in bringing together renowned and influential mainstream scholars while encouraging highly innovative niches. The most helpful and effective solutions for sustainability issues may in fact come from these niches. In my view, we should instead support approaches that legitimize new lifestyles that would consume less energy, favor the resilience of ecosystems and preserve worthwhile biodiversity while satisfying the needs of populations. We should also think of new modes of more sustainable development that would be acceptable for emerging countries, which implies questioning the forms of democracies that are best suited to provide for the population, as well as to question issues such as corruption. Research agendas such as the one carried out by the 'degrowth movement,' or on societal metabolism, seem very promising. Yet, they need to question the social desirability of these projects, as well as the institutional, cognitive, organizational, and other lock-in that impede these transitions. My contribution here has been to highlight the risks of adopting monetary valuation of ecosystem services as a privileged way of framing these discussions.

In this line of research, future studies should particularly focus on the ways in which the increase of ecosystem services valuation in the field of ecological economics arises, how it is perceived by ecological economists, and the extent to which this subject is promoted by neoclassical environmental economists. This trend raises important questions about the kind of inter- or trans-disciplinarity we as a community want for ecological economics. If ecological economics has become trans-disciplinary, do we want it to be the discipline of ecosystem services valuation? How do we want to imagine future collaboration between social scientists (in particular economists) and natural scientists (in particular ecologists)? This issue may prove to be extremely problematic in a field that claims to be based on methodological pluralism. Another subject that merits further analysis deals with the ways in which editorial choices are actually made. More attention should be paid to the editorial process as a collective decision-making procedure that results in discourse production. Ethnographical and sociological methods applied to the collective deliberation of editorial meetings would help us to understand the production of discourse and the power issues that arise in the construction of issues specific to EE.

\section{Acknowledgements}

A preliminary version of this paper was presented at the ESEE 2013 Conference in Lille (18-21 June 2103), at the LEREPS seminar in Toulouse (4 October 2013), and at the EcoEco seminar in Barcelona (16 October 2013). I thank all the participants for their remarks. I also express my 
gratitude to Tiziano Gomiero, Clive Spash, and Franck-Dominique Vivien who read this text and provided suggestions for its improvement. I also benefited from discussions with Pedro Lomas and Erik Gómez-Baggethun. I am also grateful Pierre Ratinaud and to the members of the Iramutequsers mailing list for their support. Acknowledgements finally go to Cynthia Johnson who edited this text in English.

\section{References}

Ahmed, A., Sil, R., 2012. When multi-method research subverts methodological pluralism-or, Why we still need single-method research. Perspectives on Politics 10, 935-953.

Allen, T.F.H., Giampietro, M., 2006. Narratives and transdisciplines for a post-industrial world. Systems Research and Behavioral Science 23, 595-615.

Anderson, B., M'Gonigle, M., 2012. Does ecological economics have a future? Contradiction and reinvention in the age of climate change. Ecological Economics 84, 37-48.

Barnaud C., Antona M., 2014 (forthcoming). Deconstructing ecosystem services: uncertainties and controversies around a socially constructed concept. Geoforum

Benzécri, J.-P., 1992. Correspondence analysis handbook. Marcel Dekker, New York.

Collins, H.M., 1993. The structure of knowledge. Social Research 60, 95-116.

Costanza, R., 1980. Embodied energy and economic valuation. Science 210, 1219-1224.

Costanza, R., 1989. What is ecological economics? Ecological Economics 1, 1-7.

Costanza, R., 2003. The early history of ecological economics and the International Society for Ecological Economics (ISEE), Internet Encyclopaedia of Ecological Economics, http://www.ecoeco.org/pdf/costanza.pdf.

Costanza, R., Cumberland, J.H., Daly, H.E., Goodland, R., Norgaard, R.B., 1997a. An introduction to ecological economics. St. Lucie Press and International Society for Ecological Economics, http://www.eoearth.org/article/An_Introduction_to_Ecological_Economics_\%28e-book\%29.

Costanza, R., d'Arge, R., de Groot, R., Farber, S., Grasso, M., Hannon, B., Naeem, S., Limburg, K., Paruelo, J., O'Neill, R.V., Raskin, R., Sutton, P., M., v.d.B., 1997b. The value of the world's ecosystem services and natural capital. Nature 387, 253-260.

Costanza, R., Daly, H.E., 1987. Toward an ecological economics. Ecological Modelling 38, 1-7.

Dafoe, A., 2014. Science deserves better: the imperative to share complete replication files. PS: Political Science \& Politics 47, 60-66.

Daston, L., Galison, P., 2007. Objectivity. Zone Books, New York.

Douai, A., Vivien, F.-D., 2009. Economie écologique et économie hétérodoxe : pour une socioéconomie politique de l'environnement et du développement durable. Economie Appliquée 61, 123158.

Friedman, M., 1953. The methodology of positive economics, Essays in Positive Economics. University of Chicago Press, Chicago, pp. 3-43.

Funtowicz, S.O., Ravetz, J.R., 1991. A new scientific methodology for global environmental issues, in: Costanza, R. (Ed.), Ecological economics: the science and management of sustainability. Columbia University Press, New York, pp. 137-152. 
Funtowicz, S.O., Ravetz, J.R., 1994. The worth of a songbird: ecological economics as a postnormal science. Ecological Economics 10, 197-207.

Giampietro, M., 2004. Multi-scale integrated analysis of agroecosystems. CRC Press, Boca Raton.

Gowdy, J., Erickson, J., 2005a. The approach of ecological economics. Cambridge Journal of Economics 29, 207-222.

Gowdy, J., Erickson, J., 2005b. Ecological economics at a crossroads. Ecological Economics 53, 17-20.

Habermas, J., 1992. On the pragmatics of communication. Massachusetts Institute of Technology, Boston (Edition, 1998).

Hacking, I., 1999. The social construction of what? Harvard University Press, Cambridge, MA; London, Eng.

Hacking, I., 2002. Historical ontology. Harvard University Press, Cambridge, MA.

Hanley, N., Czajkowski, M., Hanley-Nickolls, R., Redpath, S., 2010. Economic values of species management options in human-wildlife conflicts: Hen Harriers in Scotland, Ecological Economics 70, 107-113.

Harris, Z.S., Dubois-Charlier, F., 1969. L'analyse du discours. Langages 4, 8-45.

Hoepner, A.G.F., Kant, B., Scholtens, B., Yu, P.-S., 2012. Environmental and ecological economics in the 21st century: An age adjusted citation analysis of the influential articles, journals, authors and institutions. Ecological Economics 77, 193-206.

Howarth, R.B., 2009. Welcoming new board members. Ecological Economics 68, 593.

Illge, L., Schwarze, R., 2009. A matter of opinion-How ecological and neoclassical environmental economists and think about sustainability and economics. Ecological Economics 68, 594-604.

Ishiyama, J., 2014. Replication, research transparency, and journal publications: individualism, community models, and the future of replication studies. Political Science \& Politics 47, 78-83.

Kuhn, T.S., 1957. The copernican revolution: planetary astronomy in the development of western thought. Harvard University Press (Edition, 1992), Cambridge, MA.

Kuhn, T.S., 1962. The structure of scientific revolution. University of Chicago Press (Third edition, 1996), Chicago.

Latour, B., Woolgar, S., 1979. Laboratory life: the social construction of scientific facts. Princeton University Press, Princeton, New Jersey.

Lebart, L., Salem, A., 1994. Statistique textuelle. Dunod, Paris.

Luks, F., 1998. The rhetorics of ecological economics. Ecological Economics 26, 139-149.

Luks, F., 1999. Post-normal science and the rhetoric of inquiry: Deconstructing normal science? Futures 31, 705-719.

Luzadis, V.A., Castello, L., Choi, J., Greenfield, E., Kim, S.-k., Munsell, J., Nordman, E., Franco, C., Olowabi, F., 2010. The science of ecological economics: a content analysis of ecological economics, 1989-2004. Ecological Economics Reviews, Annals of the New York Academy of Sciences $1185,1-10$. 
Ma, C., Stern, D.I., 2006. Environmental and ecological economics: a citation analysis. Ecological Economics 58, 491-506.

Martinez-Alier, J., 2001. Mining conflicts, environmental justice, and valuation. Journal of Hazardous Materials 86, 153-170.

Martinez-Alier, J., 2002, The environmentalism of the poor: A study of ecological conflicts and valuation, Edward Elgar, Cheltenham.

Martinez-Alier, J., (forthcoming). Ecological economics, in: Smelser, N.J., Baltes, P.B. (Eds.), International encyclopedia of social and behavioral sciences. Elsevier, Oxford (First Edition, 2001), pp. 4016-4023.

Norgaard, R.B., 1989. The case for methodological pluralism. Ecological Economics 1, 37-57.

Norgaard, R.B., 2010. Ecosystem services: From eye-opening metaphor to complexity blinder. Ecological Economics 69, 1219-1227.

Odum, H.T., 1996. Environmental accounting: Emergy and environmental decision making. John Wiley \& Sons, New York.

Özkaynak, B., Devine, P., Rigby, D., 2002. Whither ecological economics? International Journal of Environment and Pollution 18, 317-335.

Pearce, D.W., 2002. An intellectual history of environmental economics. Annual Review of Energy and the Environment 27, 57-81.

Perelman, C., 1977. L'empire rhétorique. Rhétorique et argumentation. Librairie philosophique J. Vrin, Paris (Édition, 2002).

Ratinaud, P., Dejean, S., 2009. IRaMuTeQ : implémentation de la méthode ALCESTE d'analyse de texte dans un logiciel libre, Modélisation Appliquée aux Sciences Humaines et Sociales (MASHS2009), Toulouse - Le Mirail.

Ratinaud, P., Marchand, P., 2012. Application de la méthode ALCESTE à de "gros" corpus et stabilité des "mondes lexicaux"?: analyse du "CableGate" avec IRaMuTeQ. Actes des 11eme Journées internationales d'Analyse statistique des Données Textuelles (JADT 2012), Liège, Belgium, 835-844.

Reinert, M., 1983. Une méthode de classification descendante hiérarchique : application à l'analyse lexicale par contexte. Les cahiers de l'analyse des données 8, 187-198.

Reinert, M., 1990. ALCESTE : Une méthodologie d'analyse des données textuelles et une application: Aurélia de Gérard de Nerval. Bulletin de méthodologie sociologique 26, 24-54.

Røpke, I., 2004. The early history of modern ecological economics. Ecological Economics 50, 293314.

Røpke, I., 2005. Trends in the development of ecological economics from the late 1980s to the early 2000s. Ecological Economics 55, 262- 290.

Shi, T., 2004. Ecological economics as a policy science: Rhetoric or commitment towards an improved decision-making process on sustainability. Ecological Economics 48, 23-36.

Söderbaum, P., 2013. Ecological economics in relation to democracy, ideology and politics. Ecological Economics 95, 221-225. 
Spash, C.L., 1999. The development of environmental thinking in economics. Environmental Values 8, 413-435.

Spash, C.L., 2006. The state of ecological economics: A decade of European experience. Newsletter of the ESEE, 8-9.

Spash, C.L., 2009. The New Environmental Pragmatists, pluralism and sustainability. Environmental Values 18, 253-256.

Spash, C.L., 2011. Social ecological economics: Understanding the past to see the future. The American Journal of Economics and Sociology 70, 340-375.

Spash, C.L., 2012. New foundations for ecological economics. Ecological Economics 77, 36-47.

Spash, C.L., 2013a. Influencing the perception of what and who is important in ecological economics. Ecological Economics 89, 204-209.

Spash, C.L., 2013b. The shallow or the deep ecological economics movement? Ecological Economics 93, 351-362.

Spash, C.L., Ryan, A., 2012. Economic schools of thought on the environment: investigating unity and division. Cambridge Journal of Economics 35, 1091-1121.

Van den Bergh, J.C.J.M., 2001. Ecological economics: themes approaches, and differences with environmental economics. Regional Environmental Change 2, 13-23.

Vatn, A. 2010, An institutional analysis of payments for environmental services, Ecological Economics 69, 1245-1252.

\section{Notes}


1 This question is philosophical and is beyond the scope of science because of the autopoïtic system paradox (also known as chicken-egg paradox): producing truthful knowledge already requires having preconceived what is truth... which follows from the production of truth itself (see Hacking, 1999, for a clear and still current report on debates between realism and constrictivism). As a result, ontological positioning is a matter of a priori scientific positioning.

2 The difference between conviction and persuasion has long been the subject of intense debate. For Pascal (1670), conviction is based on reason, whereas persuasion is based on passion, while for Kant (1781), the former is objective, while the latter is subjective.

3 New topics have been added to the list relevant issues for the field: "alternative principles for valuing natural wealth, integrating natural resources and environmental services into national income and wealth accounts, methods of implementing efficient environmental policies, case studies of economic-ecologic conflict or harmony, etc".

4 Most of them were dismissed in 2002 when Cutler Cleveland was appointed Editor-in-Chief.

5 Respectively, 2.855 and 1.969 for the two-year Impact Factor and 3.732 and 2.970 for the 5-year Impact Factor as of December 2013. The Impact Factor estimates the reputation and reach of an academic review. The index is calculated as a measure of the number of cities an article from the journal gets on average compared to other journals during a two-year period or a five-year period (5-Year Impact Factor). So for year N, the value of the Impact Factor for journal X equals the number citations by other journals of the articles published in $\mathrm{X}$ during $\mathrm{N}-1$ and $\mathrm{N}-2$ of $\mathrm{N}$, divided by the number of articles published in journal $\mathrm{X}$ in the years $\mathrm{N}-1$ and $\mathrm{N}-2$.

6 There is a fundamental difference between the two tools: Alceste is payware, while Iramuteq is freeware. Although no user's manual for the latter exists yet, the software can be downloaded on the website of its creators, Pascal Marchand and Pierre Ratinaud (http://www.iramuteq.org/telechargement).

7 Signs are defined as letters $(a, b, c)$, numbers $(1,2,3)$, or underscores $\left(\_\right)$. Every other mark, such as dashes or quotation marks, drops out (e.g. "willingness-to-pay" is processed as "willingness to pay"). However, the association of certain words may have a different meaning than each one separately (as was the case in this example). To solve this problem, every occurrence of the expression is either replaced by an acronym ("wtp", in this case), or linked with underscore (e.g. in the case of "contingent_valuation"). The list of encoded forms is displayed in Appendix B.

8 In this section, the words in italics refer to the words highlighted in the descendent classification.

9 See Costanza's CV:https://crawford.anu.edu.au/sites/default/files/cv/2013/53/costanza_long_cv_6.13.pdf 


\section{Appendix 1. Preview of the analyzed corpus}

*****PY_2013 SO_EV *Dist_EV2013 *DistType_Ecol2013

using land-use módels in deliberative planning is promoted as an example of how environmental decisionmaking can be subject to both: 1) facts about how the interaction between human action and natural processes, and, 2) local perspectives on how land-use planning processes can incorporate normative concerns. this 'normative' input is often shaped and limited by the presentation of the modelled facts. this paper, however, shows that the selection and measurement of indicators, the primary outcomes of modelling exercises, are subject to a highly particular assessment, influenced by social factors, political choices and technical limitations. this revised understanding does not invalidate the use of models in participatory planning. but it does open up considerable space for stakeholders in deliberative contexts to question and challenge the evidence-based policy implications of so-called 'fact-based' modelling exercises.

$* * * * *$ PY 1989 S0_JEEM *Dist_JEEM2013 *DistType_Env1989

new policy approaches to facilitate the co existence of wildlife and livestock are needed for situations where predation incidents greatly impact households income and retaliatory killing threatens endangered carnivore species survival. in this paper, models are developed to assess how two alternative policy approaches impact a herder's decisions on carnivore hunting and livestock

protection. we find that while the well established ex post compensation policy induces suboptimal

livestock protection it can generate sufficient incentives for the herder to refrain from hunting so that the carnivore population reaches its socially optimal level. performance payments are proposed as alternative policy. they are found not to distort livestock protection incentives and can also help achieve a socially optimal carnivore population level. Which of the two scheme types gives rise to less cost is ambiguous. an empirical analysis of the model with data from tiger livestock conflicts in india is presented. 
Appendix 2. Encoded Forms

\begin{tabular}{lll}
\hline Word as found in Abstracts & & Encoded Forms \\
\cline { 1 - 2 } co2 & carbon_dioxide \\
ecological economics & & ecological_economics \\
neo-classical & neoclassical \\
multi-criteria & & multicriteria \\
payment for environmental/ecosystem service(s) & & pes \\
cost(-)benefit analysis & cba \\
environmental/ecosystem service(s) & ecosystem_services \\
gross domestic product & gdp \\
greenhouse gas & ghg \\
non forest timber product & nftp \\
georgescu-roegen & georgescu_roegen \\
ecological footprint & ef \\
environmental kuznets curve & ekc \\
cvm & contingent_valuation method \\
cv & contingent_valuation \\
wiligness(-)to(-)pay & wtp \\
$\$$ & dollar \\
$£$ & livre \\
$€$ & euro \\
\hline
\end{tabular}




\section{Appendix 3. Correspondance analysis : The two factors explaining the variability of discourses.}

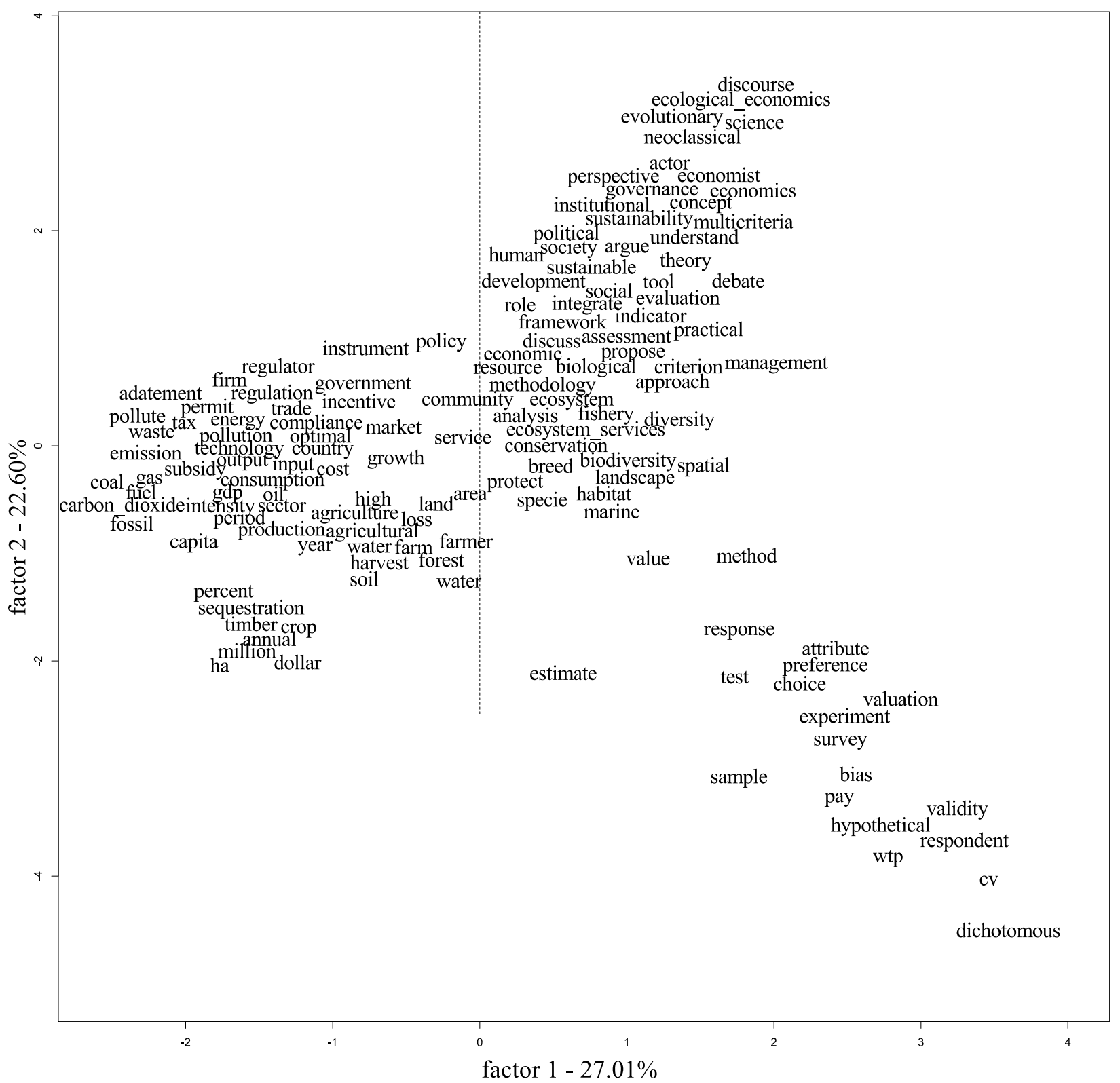

Note. This figure represents the variability of the vocabulary used in the discourse of the two fields of environmental and ecological economics. $27.01 \%$ of the inertia (first factor) explains the variability on an theoretical/methodological axis. $22.60 \%$ of the inertia (second factor) explains the variability of discourses on a empirical domain/scientific perspective axis. 